\title{
Meningkatkan Hasil Belajar Persamaan dan Fungsi Kuadrat Melalui Model Problem Based Learning dengan Kartu True or False
}

\author{
Erlin Nurhayati $1^{*}$, Lukmanul Akhsani ${ }^{2}$ \\ ${ }^{1}$ SMPN 5 Purwokerto, ${ }^{2}$ Universitas Muhammadiyah Purwokerto \\ *linurhay@gmail.com
}

Diterima: April 2020. Disetujui: Mei 2020. Dipublikasikan: Juli 2020

\begin{abstract}
ABSTRAK
Persamaan dan fungsi kuadrat adalah materi matematika yang memerlukan ketelitian dalam menghitung dan menyajikannya dalam bentuk gambar grafik. Penelitian ini bertujuan untuk meningkatkan hasil belajar matematika persamaan dan fungsi kuadrat melalui model problem based learning dengan kartu true or false. Penelitian ini dilaksanakan di SMP Negeri 5 Purwokerto Kecamatan Purwokerto Selatan Kabupaten Banyumas, bulan Juni 2019 sampai dengan Oktober 2019. Metode penelitian yang digunakan adalah penelitian tindakan kelas dengan dua siklus perbaikan pembelajaran. subyek penelitian ini adalah siswa kelas IX-H yang berjumlah 32 siswa meliputi 16 siswa laki-laki dan 16 siswa perempuan. Instrumen untuk mengupulkan data adalah lembar pengamatan siswa dalam proses pembelajaran, dokumen dan hasil tes. Hasil penelitian ini menunjukkan bahwa hasil belajar dari kondisi awal 56,32 menjadi 71,36 pada siklus II (kondisi Akhir). Jumlah siswa yang mencapai batas kriteria ketuntasan minimal pun meningkat dari 9 siswa pada kondisi awal 23 siswa pada kondisi akhir. Kesimpulan dari penelitian ini adalah bahwa penerapan model problem based learning dengan kartu true or false dapat meningkatkan hasil belajar Persamaan dan fungsi kuadrat bagi siswa.
\end{abstract}

Kata kunci: hasil belajar, problem based learning, true or false.

\begin{abstract}
Equations and Quadratic Functions are Mathematical material that requires accuracy in calculating and presenting them in graphical form. This study aims to improve the learning outcomes of Math Equations and Quadratic Functions through the Problem Based Learning model with True Or False Cards for class IX H students in semester 1 of Purwokerto 5 Middle School in the academic year 2019/2020. This research was conducted at Purwokerto 5 Middle School, Purwokerto Selatan District Banyumas Regency, from June 2019 to October 2019. The research method used was classroom action research with two cycles of learning improvement. The subjects of this study were class IX H students, amounting to 32 students with details of 16 male students and 16 female students. The instrument for gathering data is student observation sheets in the learning process, documents and test results from this study showed an increase in learning outcomes from initial conditions of 56.32 to 71.36 in the second cycle (Final conditions). In addition, the number of students who reach the minimum completeness criteria limits also increased from 9 students to the initial condition of 23 students at the final condition. The conclusion of this study is that the application of problem based learning models with true or false cards can improve learning outcomes in Equality and quadratic functions for class IX H students of Purwokerto 5 Middle School in the academic year 2019/2020.
\end{abstract}

Keywords: learning outcomes, problem based learning, true or false.

How to Cite: Nurhayati, E. \& Akhsani, L. (2020). Meningkatkan Hasil Belajar Persamaan dan Fungsi Kuadrat Melalui Model Problem Based Learning dengan Kartu True or False. Journal of Medives: Journal of Mathematics Education IKIP Veteran Semarang, 4(2), 385-391. 


\section{PENDAHULUAN}

Belajar matematika adalah belajar suatu konsep untuk membuktikan suatu fakta dan realita, untuk menemukan suatu konsep terhadap apa yang disampaikan terhadap siswa, dan ternyata tidak mudah, seperti halnya dalam mempelajari materi Persamaan dan Fungsi Kuadrat. Untuk menentukan akar persamaan kuadrat misalnya, jika penjelasan hanya dengan metode ceramah saja serta menuliskannya di papan tulis serta keterangan yang bersifat verbal belum dapat menghasilkan pemahaman yang komprehensif, para siswa sangat kesulitan untuk memahaminya, sehingga diperlukan model pembelajaran dan alat peraga yang dapat mempermudah siswa dalam belajar suatu materi.

Belajar adalah suatu aktifitas untuk menghasilkan perubahan pada diri individu. Bahwa perubahan yang diharapkan berupa kemampuankemampuan baru dalam memberikan respon terhadap stimulus yang diterima (Masyuri, 1990). Perumusan belajar dari E.R.Hilgart: "Learning is the process by which an activity ariginates or is changed trough training procedures". Belajar adalah suatu kegiatan yang mungkin dilakukan membuahkan atau menghasil-kan pada kelakuan tertentu (yang belum dimiliki sebelumnya) tetapi mungkin pula mengubah pola kelakuan (yang sudah dimiliki sebelumnya). Pola kelakuan atau tingkah laku dari seseorang dipengaruhi oleh apa yang dimiliki orang tersebut (sifat-sifatnya, pengetahuan, keterampilan-ketrampilannya, sikapnya, keadaan jasmaninya, dan sebagainya) tetapi juga dipengaruhi oleh lingkungan. Hasil belajar belajar dipengaruhi oleh bermacam-macam faktor, di antaranya adalah dorongan dari dalam diri (motif), bahan yang dipelajari, alat-alat, banyaknya waktu yang digunakan, cara belajar dan sebagainya.

Hasil belajar dapat disamakan pengertiannya dengan produk belajar. Yaitu merupakan suatu pola tertulis, nilai, makna, apresiasi, kecakapan, ketrampilan, yang berguna bagi masyarakat. (Pengembang, 1990). Ada tiga ranah hasil belajar, yaitu: kognitif, affektif, dan psikomotorik. (1) Ranah kognitif adalah hasil belajar yang berupa pengetahuan-pengetahuan atau kemampuan-kemampuan baru yang bersifat keilmuan. (2) Ranah afektif adalah hasil belajar yang berupa perubahanperubahan perilaku sebagai akibat telah dilakukannya proses belajar. Sedangkan (3) ranah psikomotor adalah hasil belajar yang berupa keterampilan-keterampilan praktis olah anggota badan.

Berdasarkan pengamatan guru matematika klas IX $\mathrm{H}$ hasil belajar matematika sangat rendah. dari hasil ulangan yang dilakukan peneliti pada kondisi awal penelitian dari 32 siswa yang mendapat nilai di atas kriteria ketuntasan minimal (KKM) hanya 9 siswa dengan rata-rata 56,32.

Selama proses pembelajaran perlu mendapatkan perhatian lebih karena pada proses pembelajaran diharapkan terjadi interaksi, kolaborasi dan komunikasi langsung antara guru dengan siswa, siswa dengan guru dan siswa dengan siswa yang lain sehingga siswa dapat termotivasi tidak bosan dalam mengikuti proses belajar. 
Berdasarkan masalah di atas diperlukan model pembelajaran yang efektif, kreatif, dan menyenangkan. salah satunya adalah model pembelajaran Problem Based Learning (PBL) dan adanya alat peraga untuk memudahkan siswa memahami materi yang dipelajari yaitu dengan kartu true or false sehingga menjadikan pembelajaran lebih menarik, menantang, dan menyenangkan bagi siswa sehingga diharapkan hasil belajar matematika siswa dapat meningkat.

Menurut Arends dalam (Trianto, 2014), PBL memiliki karakteristik: (1) Pengajuan pertanyaan atau masalah, (2) Berfokus pada keterkaitan antardisiplin ilmu, (3) Penyelidikan autentik, (4) Menghasilkan produk dan memerkannya, dan (e) Kolaborasi. Menurut Sujiranto (2018) Pembelajaran berbasis masalah memiliki kelebihan dalam hal: (1) menjadikan pembelajaran berpusat pada siswa; (2) mendorong siswa untuk mengembangkan diri secara holistik atau menyeluruh yaitu melatih kemandirian, kemampuan bekerja dalam kelompok, dan menanggapi tantangan dalam menyelesaikan suatu permasalahan; (3) meningkatkan kemampuan komunikasi; (4) mengembangkan kemampuan berinteraksi sosial; (5) mendorong siswa mendapatkan pengetahuan yang lebih dalam; (6) mengembangkan ketrampilan siswa dalam pemecahan masalah; dan (7) meningkatkan semangat dan motivasi siswa untuk belajar.

Berdasarkan hasil penelitian (Misu, 2015), menyatakan bahwa penggunaan perangkat pembelajaran PBL setting minemapping dapat efektif, ditunjukkan dengan ketuntasan $88,1 \%$. Hal ini menunjukkan PBL memang perlu digunakan dalam pemebelajaran dalam menghadapi hasil belajar yang masih rendah. Kemampuan dalam menalar soal matematika juga penting dalam pembelajaran sehingga siswa dapat mengerjakan soal. Sejalan dengan (Maharani, 2019), desain bahan ajar persamaan kuadrat dengan PBL berbasi kemampuan penelaran matematis dapat memeperbaiki kualitas penalaran siswa.

Langkah-langkah strategi pembelajaran True or False adalah sebagai berikut (Silberman, 2007): (1) guru membuat daftar pernyataan yang sesuai dengan materi pelajaran, yang isinya benar dan salah. Pernyataan ditulis dalam kartu masing-masing secara terpisah dan pastikan jumlah pernyataan tersebut sesuai dengan jumlah siswa, (2) bagikan kartu masing-masing satu kepada siswa. Guru menginformasikan kepada siswa tentang tujuan pembelajaran. (3) ketika mata pelajaran selesai, mintalah masing-masing siswa membaca kartu yang diperolehnya dan dapatkan opini kelas tentang pernyataan itu benar atau salah, (3) guru memberikan tanggapan tentang kebenaran atau kesalahan untuk masing-masing kartu tersebut, dan (4) Guru memberikan simpulan.

Adapun Tujuan dari penelitian ini adalah untuk meningkatkan hasil belajar persamaan dan fungsi kuadrat pada siswa kelas IX H SMP Negeri 5 Purwokerto tahun pelajaran 2019/2020.

\section{METODE PENELITIAN} Waktu dan Tempat Penelitian

Penelitian ini dilakukan dari bulan Juni 2019 sampai dengan Oktober 2019. Penelitian ini kami lakukan kepada siswa Sekolah Menengah Pertama, yang 
kami jadikan tempat penelitian adalah SMP Negeri 5 Purwokerto Kabupaten Banyumas.

\section{Subyek Penelitian}

Subyek penelitian seluruh siswa kelas IX H SMP Negeri 5 Purwokerto sejumlah 32 siswa dengan rincian 16 siswa putri dan 16 siswa putra.

\section{Sumber Data}

Pengumpulan data dalam penelitian ini, yaitu: (1) data hasil belajar matematika siswa dalam pembelajaran Persamaan Kuadrat awal penelitian dikumpulkan dengan teknik tes tertulis (Penilaian harian I) (2) data hasil belajar matematika siswa dalam pembelajaran fungsi kuadrat dengan menggunakan model Problem based learning (PBL) dengan kartu true or false siklus I diperoleh dengan teknik tes tertulis (penilaian harian II), (3) data hasil belajar matematika dalam pembelajaran fungsi kuadrat dengan menggunakan model Problem based learning (PBL) dengan kartu true or false siklus I diperoleh dengan teknik tes tertulis (penilaian harian III).

\section{Hipotesis Tindakan}

Berdasarkan penjelasan di atas diajukan hipotesis tindakan dalam penelitian ini adalah "melalui model problem based learning dengan kartu true or false dapat meningkatkan hasil belajar persamaan dan fungsi kuadrat bagi siswa kelas IX H semester 1 SMP Negeri 5 Purwokerto kabupaten Banyumas tahun pelajaran 2019/2020.

\section{HASIL DAN PEMBAHASAN}

Pada kondisi awal pembelajaran Persamaan kuadrat hasil penilaian harian 1 masih sangat rendah,ini ditunjukan hasil penilaian belajar siswa dengan KKM 68 nilai yang mencapai ketuntasan dari 32 siswa hanya 9 siswa atau $28,13 \%$, Sedangkan sisanya 23 siswa atau 71,87\% masih belum mencapai KKM (belum tuntas), nilai terendah 25, nilai tertinggi 82 dan rata-ratanya 56,32. Ternyata ratarata kelas masih jauh di bawak KKM. Jumlah siswa yang memperoleh nilai di atas rata-rata kelas adalah 12 siswa atau $37,50 \%$ saja sedangkan sisanya 20 atau $62,50 \%$ siswa memperoleh nilai di bawah rata-rata kelas. Hal ini dikarenakan guru masih terlalu banyak berceramah dan menjadi pusat pembelajaran, siswa menjadi bosan karena hanya menjadi pendengar kurang terjadi interaksi antara siswa dengan guru dan siswa dengan siswa. Kegiatan pembelajaran kurang menarik dan siswa menjadi mengantuk atau cerita sendiri. Peneliti belum menggunakan model pembelajaran problem based learning dengan kartu true or false. Hasil belajar matematika siswa pada siklus I diperoleh dari hasil ulangan harian pada siklus I yaitu sebagai berikut.

Tabel 2. Nilai Perubahan Hasil Belajar Siklus I

\begin{tabular}{clc}
\hline No. & \multicolumn{1}{c}{ Uraian } & Nilai \\
\hline 1. & Nilai Terendah & 30 \\
2. & Nilai Tertinggi & 90 \\
3. & Nilai Rerata & 64,18 \\
4. & Rentang Nilai & 60 \\
5. & Terlampaui & 15 \\
6. & Tercapai & 4 \\
7. & Belum Tercapai & 13 \\
8. & Persentase Ketuntasan Hasil & 59,38 \\
& Belajar & \\
\hline
\end{tabular}


Hasil belajar matematika siswa pada siklus II diperoleh dari hasil ulangan harian pada siklus II yaitu sebagai berikut.

Tabel 3. Nilai Perubahan Hasil Belajar Siklus II

\begin{tabular}{clc}
\hline No. & \multicolumn{1}{c}{ Uraian } & Nilai \\
\hline 1. & Nilai Terendah & 30 \\
2. & Nilai Tertinggi & 100 \\
3. & Nilai Rerata & 71,36 \\
4. & Rentang Nilai & 70 \\
5. & Terlampaui & 17 \\
6. & Tercapai & 4 \\
7. & Belum Tercapai & 11 \\
8. & Persentase Ketuntasan & 65,62 \\
& Hasil belajar & \\
\hline
\end{tabular}

Hasil belajar matematika siswa dari penilaian harian kondisi awal penelitian, siklus I, dan siklus II disajikan dalam bentuk tabel adalah sebagai berikut.

Tabel 4. Nilai Perubahan Hasil Belajar Kondisi Awal, Siklus I dan Siklus II

\begin{tabular}{|c|c|c|c|}
\hline No. & $\begin{array}{c}\text { Kondisi } \\
\text { Awal }\end{array}$ & Siklus I & Siklus II \\
\hline \multirow[t]{2}{*}{1.} & Nilai & Nilai & Nilai \\
\hline & $\begin{array}{l}\text { Terendah: } \\
25\end{array}$ & Terendah: 30 & $\begin{array}{l}\text { Terendah: } \\
30\end{array}$ \\
\hline \multirow[t]{2}{*}{2.} & Nilai & Nilai & Nilai \\
\hline & $\begin{array}{l}\text { Tertinggi: } \\
82\end{array}$ & Tertinggi: 90 & $\begin{array}{l}\text { Tertinggi: } \\
100\end{array}$ \\
\hline \multirow[t]{2}{*}{3.} & Nilai & Nilai Rerata: & Nilai \\
\hline & $\begin{array}{l}\text { Rerata: } \\
56,32\end{array}$ & 64,18 & $\begin{array}{l}\text { Rerata: } \\
71,36\end{array}$ \\
\hline \multirow[t]{2}{*}{4.} & Tuntas & Tuntas & Tuntas \\
\hline & $\begin{array}{l}\text { Belajar:9 } \\
\text { siswa }\end{array}$ & $\begin{array}{l}\text { Belajar:19 } \\
\text { siswa }\end{array}$ & $\begin{array}{l}\text { Belajar: } 21 \\
\text { siswa }\end{array}$ \\
\hline \multirow[t]{2}{*}{5.} & Belum & Belum & Belum \\
\hline & $\begin{array}{l}\text { Tuntas: } 23 \\
\text { siswa }\end{array}$ & $\begin{array}{l}\text { Tuntas: } 13 \\
\text { siswa }\end{array}$ & $\begin{array}{l}\text { Tuntas: } 11 \\
\text { siswa }\end{array}$ \\
\hline \multirow[t]{4}{*}{6.} & Persentase & Persentase & Persentase \\
\hline & Ketuntasan & Ketuntasan & Ketuntasan \\
\hline & Hasil & Hasil Belajar: & Hasil \\
\hline & $\begin{array}{l}\text { Belajar: } \\
37,50\end{array}$ & 59,38 & $\begin{array}{l}\text { Belajar: } \\
65,62\end{array}$ \\
\hline
\end{tabular}

Keberhasilan ini tidak lepas dari usaha guru dalam melaksanakan pemebelajaran. Pemebelajaran menggunakan model Problem based learning sangat membantu dalam meningkatkan motivasi belajar siswa. Dengan meningkatnya motivasi belajar siswa, siswa akan lebih fokus dan memeiliki tujuan dalam belajar matematika. Hal ini sejalan dengan hasil penelitian (Arief \& Sudin, 2016), bahwa model pemebelajaran Problem Based Learning dapat meningkatkan motivasi belajar siswa.

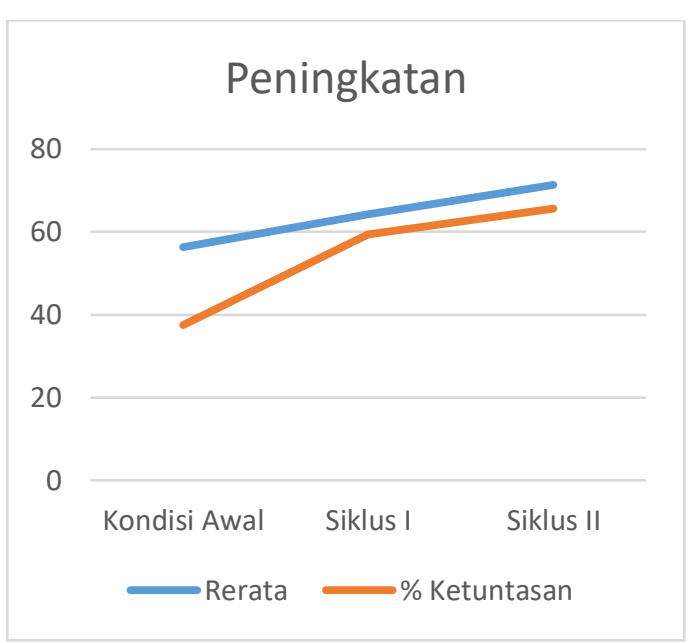

Gambar 1. Peningkatan Rerata Hasil Belajar dan Ketuntasan Belajar

Kemampuan siswa dalam memecahkan masalah juga menjadi pengaruh dalam menegrjakan soal yang diberikan oleh guru. Siswa dengan kemampuan pemecahan masalah yang baik akan dapat memahami soal dan merencanakan penyelesaiannya, sampai dengan penarikan kesimpulan dan pengecekan kembali. Hal ini sejalan juga dengan penelitian (Supiandi \& Julung, 2016), model PBL meningkatkan kemampuan memecahkan masalah dan hasil belajar kognitif pada siswa.

Hal yang mempengaruhi juga pada penggunaan kartu true or false. Penggunaan kartu ini biasanya ada pada strtegi pemebelajaran true or false. Dalam penelitian ini dipadukan dengan 
PBL menjadikan lebih menarik. Penggunaan kartu ini membuat siswa menjadi senang dan tertantang dalam pemebelajaran. Pemebalajran yang menyenangkan dan menantang merupakan salah satu hal penting yang harus diperhatikan guru agar pembelajaran lebih hidup.

Sejalan dengan penelitian (Erikalisdiana \& Jayadinata, 2016), penggunaan startegi true or false lebih baik dalam meningkatkan hasil belajar siswa. Perpaduan PBL dan true or false sangat menarik bagi pembalajaran di kelas. Penelitian lain oleh Akhsani \& Muhammad (2017); Yelly (2017); Leo, Noviandini, \& Pattiserlihun (2018); Nurhayati (2017) bahwa dengan media kartu true or false dapat meningkatkan hasil belajar dan partisipasi belajar siswa.

\section{PENUTUP}

Melalui model problem based learning dengan kartu true or false dapat meningkatkan hasil belajar persamaan dan fungsi kuadrat bagi siswa kelas IX H semester 1 SMP Negeri 5 Purwokerto kabupaten Banyumas tahun pelajaran 2019/2020.

Saran yang perlu diperhatikan sehubungan dengan model problem based learning dengan kartu true or false dapat meningkatkan hasil belajar persamaan dan fungsi kuadrat adalah bahwa model problem based learning dengan kartu true or false bukanlah satusatunya alternatif model pembelajaran tetapi hendaknya guru dapat menentukan model pendekatan pembelajaran yang tepat dan sesuai dengan materi yang diajarkan.

\section{DAFTAR PUSTAKA}

Akhsani, L., \& Muhammad, M. (2017). Strategi True Or False dengan Media Kartu Indeks pada Mata Kuliah Teori Graf. AlphaMath: Journal of Mathematics Education, 2(2).

Arief, H. S., \& Sudin, A. (2016). Meningkatkan Motivasi Belajar Melalui Pendekatan ProblemBased Learning (Pbl). Meningkatkan Motivasi Belajar Melalui Pendekatan ProblemBased Learning (Pbl), 1(1), 141150. https://doi.org/10.23819/ pi.v1i1.2945

Erikalisdiana, D. S., \& Jayadinata, A. K. (2016). Pengaruh Penggunaan Strategi True Or False Terhadap Hasil. Jurnal Pena Ilmiah, 1. https://ejournal.upi.edu/index.php/ penailmiah/article/view/3565/pdf

Leo, S., Noviandini, D., \& Pattiserlihun, A. (2018). Metode Pengembangan Media Pembelajaran Model True or False Physics Fun Game Card. Radiasi: Jurnal Berkala Pendidikan Fisika, 11(2), 65-72.

Maharani, A. (2019). Desain Bahan Ajar Materi Persamaan Kuadrat dengan Problem Based Learning Berbasis Kemampuan Penalaran Matematis Siswa. Euclid, 6(1), 53. https://doi.org/10.33603/e.v6i1.18 51

Masyuri, H. (1990). Asas-Asas Pembelajaran. IKIP Semarang Press.

Misu, L. (2015). Development of Settingmind Problem Based Learning (Pbl) Learning Devices Mapping Material Equations and Function of Squares in Class $\mathrm{X}$ Students. Journal Education Mathematics, 6(2), 139-157. 
Nurhayati, N. (2017). Peningkatan Partisipasi dan Hasil Belajar Siswa Kelas IVA dalam Pembelajaran Pai dengan Strategi True Or False di SD Negeri 21 Batang Anai. JPPI (Jurnal Penelitian Pendidikan Indonesia), 3(2), 3043.

Pengembang, T. (1990). Psikologi Belajar. IKIP Semarang Press.

Silberman, M. . (2007). Active Learning (diterjemahkan Sarjuli.dkk). Pustaka Insan Madani.

Sujiranto. (2018). Model Pembelajaran Guru Abad 21. Mujahid Press.

Supiandi, M., \& Julung, H. (2016). Pengaruh Model Problem Based Learning (PBL) terhadap Kemampuan Memecahkan Masalah dan Hasil Belajar Kognitif Siswa Biologi SMA. JPS (Jurnal Pendidikan Sains), 4(2), 60-64. https://doi.org/10.17977/jps.v4i2. 8183

Trianto. (2014). Mendesain Model Pembelajaran Inovatif, Progresif dan Kontekstual. Prenadamedia Group.

Yelly, A. (2017). Pengaruh Penggunaan Strategi Pembelajaran Aktif Tipe True or False Terhadap Hasil Belajar Fisika Siswa Kelas XI IPA SMAN 14 Padang (Doctoral dissertation, STKIP PGRI Sumatera Barat). 